\title{
A HISTORICAL ANALOG OF 2005 HURRICANE VINCE
}

by J. M. Vaquero, R. García-Herrera, D. Wheeler, M. Chenoweth, and C. J. Mock

The passage of Hurricane Vince as a tropical depression over Spain and Portugal was once thought to be a unique historical event, but documents show that a rare tropical storm similarly struck southwest Spain in October 1842.

0 $\mathrm{n}$ the occasion of the appearance of Vince as a tropical depression over the Iberian Peninsula (Portugal and Spain) in October 2005, both the informed and the popular media were unequivocal in asserting it to be the first occasion when such an event had been recorded. However, the accepted and existing database upon which this fact was based begins in 1851. Climatologists are analyzing historical records to gain a longer-term perspective of meteorological extremes and variability. Lamb (1991) offers a good

AfFiliations: VAquero-Departamento de Física Aplicada, Escuela Politécnica, Universidad de Extremadura, Cáceres, Spain; García-Herrera-Departamento Física de la Tierra II, Facultad de CC Físicas, Universidad Complutense de Madrid, Madrid, Spain; WheELER-Geography Department, University of Sunderland, Sunderland, United Kingdom; CHENOWETH_Elkridge, Maryland; Моск-Department of Geography, University of South Carolina, Columbia, South Carolina

CORRESPONDING AUTHOR: José M. Vaquero, Departamento de Física Aplicada, Escuela Politécnica, Universidad de Extremadura, Avda de la Universidad s/n, I007I Cáceres, Spain E-mail: jvaquero@unex.es

The abstract for this article can be found in this issue, following the table of contents.

DOI:|0.|I75/BAMS-89-2-|9|

In final form 7 September 2007

(02008 American Meteorological Society example of this use of historical storm records for the British Isles and North Sea region. Camuffo et al. (2000) have been equally successful with respect to storm chronologies for the western Mediterranean, while Brázdil et al. (2004) have conducted a similar exercise for storm activity in central Europe. Referring more specifically to Atlantic hurricanes, Chenoweth (2006), García-Herrera et al. (2005a), and Mock et al. (2004) have drawn heavily on documentary sources to improve the evidence base for hurricane activity in the western Atlantic region, while Chenoweth and Landsea (2004) provide a detailed case study for a rare California hurricane. Chenoweth and Landsea (2004) employ largely the same variety and type of source material (newspapers, personal accounts, and instrumental data) as has been called upon in the preparation of the current paper. Elsewhere, Chinese and Spanish documentary sources have also been used to obtain chronologies of typhoons in the western Pacific basin (Liu et al. 2001; Ribera et al. 2005; García-Herrera et al. 2007).

This paper contributes to this same area of research, but with a sharper temporal focus that combines different documentary sources to analyze an unusual episode of severe stormy weather that occurred in Spain in October 1842, and one that bears some resemblance to Hurricane Vince of 2005. Use is made of documents and records ranging from ships' logbooks kept in British archives, to hurricane 
records from published U.S. and Spanish sources to contemporary instrumental data.

\section{SEVERE WEATHER IN SPAIN (29 OCTOBER}

1842). A detailed account of the storm that struck Spain toward the close of October 1842 is given by Rico Sinobas (1853). This document contains various items that appeared in the Spanish press and describes what the author assumed to be a hurricane that originated in the Gulf of Mexico at the beginning of October (an assumption to which the authors do not subscribe). Rico Sinobas supplements these narrative accounts with meteorological data, again published in the Spanish press. It is important to note that his credentials as an academic reporter are impressive: he held a doctorate in medicine and was one of Spain's leading nineteenth-century physicists, with a chair at the University of Madrid; he was also vice president of the Academy of Sciences in the same city. He published works on meteorology (Vaquero et al. 2003) and a physics textbook, which has several editions. His comments can be regarded, therefore, as worthy of note and based on sound scientific understanding.

According to this author, the storm was first detected over Madeira, Portugal, on the night of 27 October and continued into the following morning. The most severe damage seems to have been in Funchal (the principal port of the Madeira island group), which was a consequence of some notably violent squalls. During the night of 28 and 29 October, the hurricane arrived off the northeast coast of Africa, close to Cape Blanco and Cape Spartel, Morocco. Rico Sinobas also drew upon the testimony of mariners onboard the Spanish vessel Buenmozo, then making her way from the Canaries to San Lúcar de Barrameda (close to Cádiz), Spain, where she arrived on 30 October, having survived the storm.

The effects of this storm were noted also over Spain on the night of 28 October. In the Bay of Cádiz (Fig. 1) the wind was very strong from dusk until $0430 \mathrm{LT}^{1}$ 29 October when it began to decline in strength. Many vessels in the area suffered some damage, trees were uprooted, and two bridges were swept away. Trees in Jerez de la Frontera were also uprooted by violent southerly winds. Farther south, in Conil, three ships were driven ashore. According the Spanish naval sources in Cádiz, 3 of their vessels were lost and 45 other ships of various nationalities were severely damaged. In Málaga, the French brigantine Doumesnil was driven ashore within site of the town by the heavy seas and strong levante (southeasterly) wind.

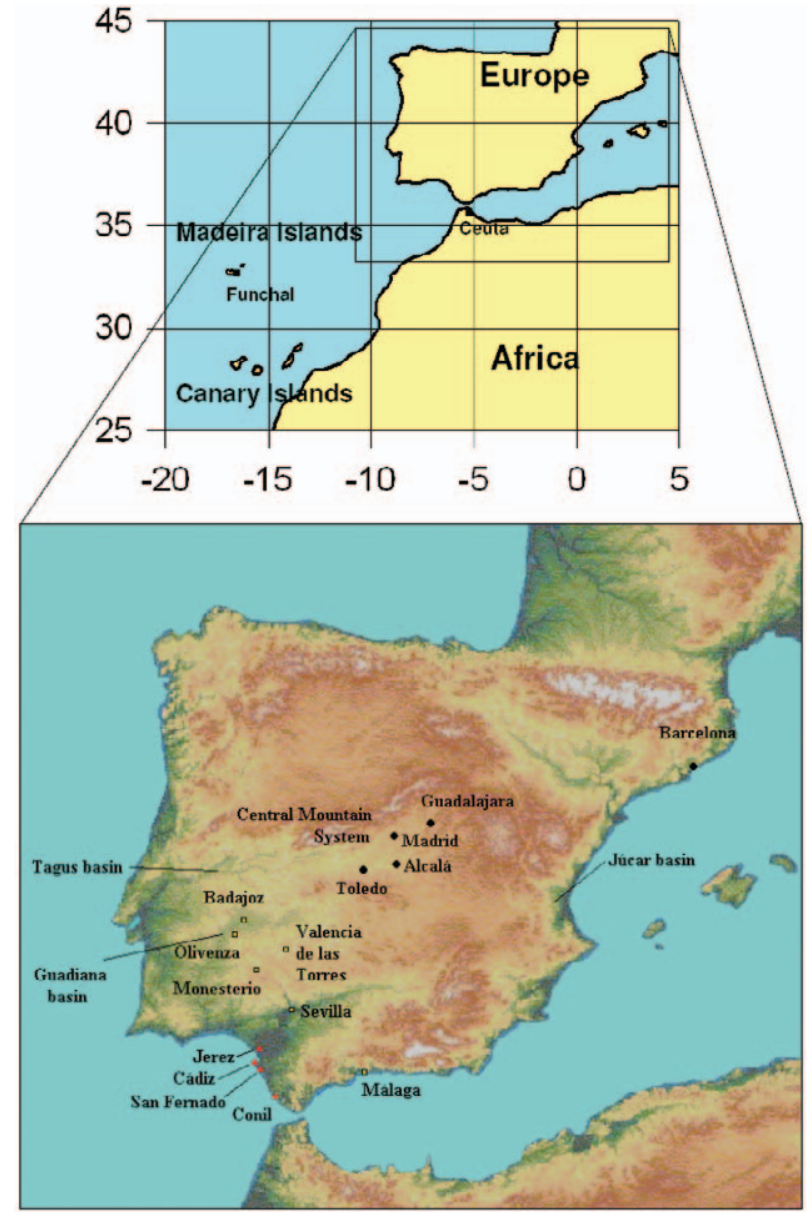

FIG. I. Map showing the locations cited in the text. The enlarged area shows the locations affected by severe weather on 29 Oct 1842 and cited by Rico Sinobas (1853). The wind reached its maximum velocity during the early morning of 29 Oct in all of those places indicated with a triangle. Those places where the maximum was achieved during the late morning (early afternoon) are denoted by a square (circle). The colors of the symbols are a schematic representation of the observed damage: red, trees uprooted and demolished buildings; yellow, damage to buildings and trees; black, minor damage to buildings.

During the morning of 29 October the effects of the storm became apparent elsewhere in the Andalusia region of southern Spain and in the south of the Extremadura region (west-central part of Spain). In many places it blew with great force between 0400 and $1400 \mathrm{LT}$, again causing damage to buildings and trees and to ships navigating the Guadalquivir River. Rico Sinobas was able to secure meteorological data from only a few places in the southwest of Spain: San Fernando, near Cádiz, and Seville (Table 1). It is almost certain that those he cites

${ }^{1}$ All times are cited as in the original documents and local times, the present-day system of time zones not then being in use. 


\begin{tabular}{|c|c|c|c|c|}
\hline Location & Hour & Wind description & $\begin{array}{c}\text { Estimated } \\
\text { Beaufourt force }\end{array}$ & Barometer (in.) \\
\hline \multirow{5}{*}{ San Fernando } & Dawn, 28 Oct & East, strong & 7 & - \\
\hline & 0400 LT, 29 Oct & Southeast hurricane & 12 & - \\
\hline & 0900 LT, 29 Oct & South hurricane & 12 & 29.03 \\
\hline & I200 LT, 29 Oct & Southwest, violent & 8 & 29.36 \\
\hline & I500 LT, 29 Oct & Light winds & 2 & 29.50 \\
\hline \multirow{3}{*}{ Seville } & 0900 LT, 29 Oct & Southeast, hurricane & 12 & 28.90 \\
\hline & 1200 LT, 29 Oct & Southwest, violent & 8 & Increasing rapidly \\
\hline & 1400 LT, 29 Oct & Light winds & 2 & 29.32 \\
\hline
\end{tabular}

from San Fernando are taken from the records of the Observatorio de la Marina (Royal Navy Observatory), although he also drew from items in the local press. The storm was clearly widespread, and during the morning of 29 October various locations farther inland, particularly in the region of Extremadura around Olivenza, Monesterio, and Valencia de las Torres, also experienced the stormy conditions. Violent gusts were recorded in several places. There was notable damage to wooded areas, with thousands of trees uprooted in the province of Badajoz alone. The storm was also felt in the basin of the Tagus River. Problems were reported in Toledo, Madrid, Alcalá, and Guadalajara. Rico Sinobas provides meteorological data for 3-hourly intervals during 28 and 29 October. The pressure at Madrid reached its lowest point at 1500 LT 29 October, but the actual recorded values are considered to be too low; however, the magnitude of this bias cannot be determined because of a lack of metadata. From that point until 2100 LT the winds were recorded variously as being either of hurricane force or severe. Pressure recovered rapidly on 30 October, when the conditions soon became calm (Table 2). Additional information has more recently become available from private observations made in Cádiz (Barriendos et al. 2002). Using these, Fig. 2 depicts the surface pressure changes, which include the notable fall of $13.3 \mathrm{hPa}$ in the $24 \mathrm{~h}$ between 28 and 29 October. Because these data are based on midday "fixed hour" observations, they may underestimate the extreme values and changes, some of which took place during the intervening periods.

Farther afield, the Spanish national press published reports of damage in the basin of the Júcar River in southeast Spain. But, not all of Spain fell under the sway of this storm, and according to Rico Sinobas the Central Mountain system of Spain (see Fig. 1) acted as the boundary between the sectors where it was experienced and those where it was not in evidence.
With notable prescience, Rico Sinobas concludes his analysis by drawing attention to the possibility of using the logbooks of the far-traveled Spanish ships for the study of hurricanes in general:

[such studies] lead to an understanding of the winds that ancient mariners termed tornadoes or violent squalls, data and observations for which our nation should have in abundance in the nautical registers not only for the Antilles Sea [the Caribbean] but also for her possessions in the Pacific where one rarely spends much time without encountering hurricanes from the Rodriguez Islands (Rico Sinobas 1853, p. 74).

\section{SEARCHING FOR THE TRAJECTORY OF} THE HURRICANE. In order to assess the possible tropical origin of this event, further analyses were conducted with a view to confirm the trajectory and intensity of the 1842 event. In particular, attention was concentrated on the most recent Atlantic hurricane chronology (Chenoweth 2006) for the post- 1700 period, with additional evidence from Spanish sources (García-Herrera et al. 2005a), the Climatological Database for the World's Oceans (CLIWOC) database (García-Herrera et al. 2005b), and the logbooks kept in British and U.S. archives. In total, 4 logbooks from the U.S. Maury collection and an additional 15 logbooks of ships of the Royal Navy were examined.

The last two hurricanes of the season of 1842 in the western Atlantic Ocean occurred in October. One of them passed Galveston, Texas, on 5 October, causing flooding and sinking one ship. It continued eastward, becoming a major hurricane and arriving near St. Marks, Florida, where it caused $\$ 500,000$ of damage before moving out to sea on 10 October. This hurricane is described in great detail by Redfield (1846). The next storm was first detected east of Miami on 26 October. It tracked close to the coast- 


\begin{tabular}{|c|c|c|c|c|c|}
\hline Day & $\begin{array}{l}\text { Time } \\
\text { (LT) }\end{array}$ & $\begin{array}{c}\text { Pressure } \\
(\mathrm{hPa})\end{array}$ & $\begin{array}{c}\text { Temperature } \\
\left({ }^{\circ} \mathrm{C}\right)\end{array}$ & Wind & State \\
\hline $28 \mathrm{Oct}$ & $\begin{array}{l}0600 \\
0900 \\
1200 \\
1500 \\
1800 \\
2100 \\
2400\end{array}$ & $\begin{array}{l}1,014.6 \\
1,013.5 \\
1,009.6 \\
1,007.5 \\
1,005.6 \\
1,005.2 \\
, 002.1\end{array}$ & $\begin{array}{l}08.75 \\
09.68 \\
10.00 \\
10.62 \\
10.62 \\
10.62 \\
10.00\end{array}$ & $\begin{array}{l}\text { Northeast } \\
\text { Northeast } \\
\text { Northeast } \\
\text { Northeast } \\
\text { North } \\
\text { Calm } \\
\text { East }\end{array}$ & $\begin{array}{l}\text { Rain } \\
\text { Rain } \\
\text { Rain } \\
\text { Rain } \\
\text { Rain } \\
\text { Cloudy } \\
\text { Rain }\end{array}$ \\
\hline 29 Oct & $\begin{array}{l}0600 \\
0900 \\
1200 \\
1500 \\
1800 \\
2100 \\
2400\end{array}$ & $\begin{array}{l}999.7 \\
998.97 \\
994.21 \\
985.5 \\
987.5 \\
1,001.7 \\
1,005.9\end{array}$ & $\begin{array}{l}10.62 \\
11.87 \\
12.50 \\
13.75 \\
12.25 \\
09.37 \\
08.75\end{array}$ & $\begin{array}{l}\text { Northeast } \\
\text { East } \\
\text { Southeast } \\
\text { Southeast, hurricane } \\
\text { Southeast, hurricane } \\
\text { Southwest, strong } \\
\text { Southwest }\end{array}$ & $\begin{array}{l}\text { Rain } \\
\text { Cloudy } \\
\text { Rain } \\
\text { Rain } \\
\text { Cloudy } \\
\text { Cloudy } \\
\text { Cloudy }\end{array}$ \\
\hline 30 Oct & $\begin{array}{l}0600 \\
0900 \\
1200 \\
1500 \\
1800 \\
2100 \\
2400\end{array}$ & $\begin{array}{l}1,010.4 \\
1,015.3 \\
1,015.7 \\
1,016.5 \\
1,017.9 \\
1,020.2 \\
1,021.3\end{array}$ & $\begin{array}{l}08.43 \\
09.37 \\
11.87 \\
11.87 \\
11.25 \\
10.00 \\
09.37\end{array}$ & $\begin{array}{l}\text { Southwest } \\
\text { North } \\
\text { Calm } \\
\text { North } \\
\text { Northeast } \\
\text { Northeast } \\
\text { Northeast }\end{array}$ & $\begin{array}{l}\text { Mist } \\
\text { Mist } \\
\text { Cloudy } \\
\text { Clear } \\
\text { Cloudy } \\
\text { Cloudy } \\
\text { Cloudy }\end{array}$ \\
\hline
\end{tabular}

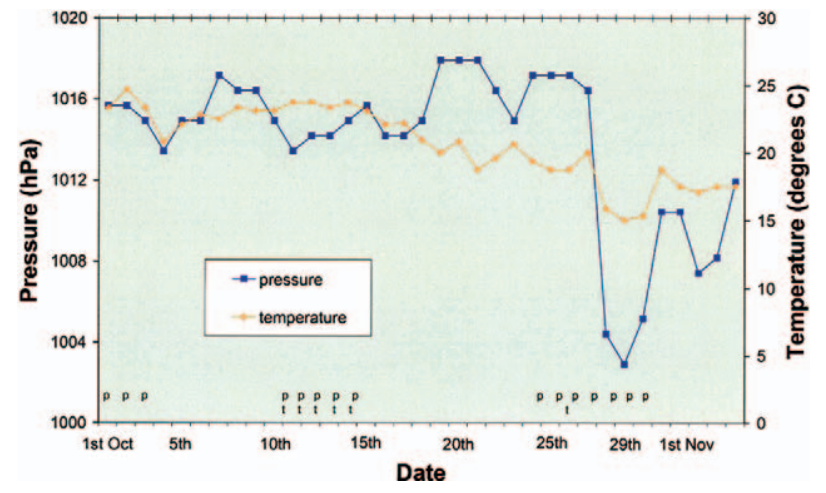

FIG. 2. Daily pressure evolution for Oct and early Nov 1842 based on data from private observations in Cádiz. The figure includes days of rain $(p)$ or thunderstorm $(t)$.

lines of Florida, Georgia, and South Carolina before dissipating on 30 October. The timing of both of these hurricanes suggests that neither could account for the events over Spain after 28 October. Redfield's otherwise detailed account of Atlantic hurricanes, particularly those of the Caribbean region, is mute on the question of the events at the month's conclusion in the eastern Atlantic. Fortunately, further insight was provided by logbook information from ships of the
British Royal Navy. Admiralty fleet lists held at the U.K. National Archive (catalog series ADM/8) record the whereabouts of Royal Navy ships on a month-bymonth basis. A search of these documents identified some 20 ships in the North Atlantic and Caribbean region at this time, for which the official logbooks have survived (and can be found in the U.K. National Archives series ADM/51 and ADM/52). Only one of them, Her Majesty's Ship (HMS) Volcano, was in passage across the Atlantic (from Halifax, Nova Scotia, Canada to the United Kingdom). Interestingly, neither the Volcano nor any other ships elsewhere in the Atlantic region experienced gales or storms at times that would associate them with the Spanish system of late October, and no reference to hurricanes could be found even in the logbooks of ships in the West Indies. This negative but otherwise useful finding suggests that the Spanish system may not have followed the conventional hurricane trajectory across the Atlantic, then recurving around the subtropical "high" to approach Europe, but leaves unanswered the question of its true trajectory.

Further light on the issue is cast by the edition of The Barbadian (a newspaper published in the West Indies) for 7 December 1842, which describes 
TABLE 3. Abridged entries in the logbook of HMS Warspite (Oct 1842).

\begin{tabular}{|c|c|c|c|c|c|}
\hline \multirow{2}{*}{$\begin{array}{c}28 \text { Oct } \\
\text { Time (LT) }\end{array}$} & \multirow{2}{*}{\multicolumn{2}{|c|}{$\begin{array}{l}37.04^{\circ} \mathrm{N} \\
\text { Force* }\end{array}$}} & \multicolumn{3}{|c|}{$09.22^{\circ} \mathrm{W}$} \\
\hline & & & $\begin{array}{c}\text { Weather* } \\
\text { (Beaufort notation) }\end{array}$ & $\begin{array}{l}\text { Barometer } \\
\text { (in.) }\end{array}$ & $\begin{array}{c}\text { Thermometer } \\
\left({ }^{\circ} \mathrm{C}\right)\end{array}$ \\
\hline 0300 & Southerly & 2 & $b, c$ & 29.82 & 68 \\
\hline 0600 & & & Variable & & \\
\hline 1200 & & 3 & o, c & 29.80 & 68 \\
\hline 1500 & Southerly & 3 & c & 29.65 & 70 \\
\hline 1900 & & 4 & $c, g$ & 29.60 & 68 \\
\hline 2200 & & 6 & $u, g$ & 29.46 & 72 \\
\hline 29 Oct & & $36.20^{\circ} \mathrm{N}$ & & $09.11^{\circ} \mathrm{W}$ & \\
\hline 0300 & Southerly & 6 & $\mathrm{u}, \mathrm{c}$ & & \\
\hline 0500 & East-southeast & 8 & $q, r$ & 29.10 & 70 \\
\hline 0800 & North-northeast & 9 & $q, r$ & 29.25 & 70 \\
\hline 1100 & North-northwest & 8 & $\mathrm{q}, \mathrm{o}$ & 29.50 & 67 \\
\hline 1600 & Northwest & 8 & $b, c$ & 29.58 & \\
\hline 2000 & Westerly & 4 & & 29.60 & 67 \\
\hline 2400 & South-southwest & & & 29.60 & \\
\hline
\end{tabular}

At this time a version of the Beaufort scale was coming into wide use by Royal Navy officers. The wind forces noted above are described as follows: 2 = light air, 3 = gentle breeze, $4=$ moderate breeze, $6=$ strong breeze, $8=$ gale, $9=$ strong gale. The weather scale key is provided by $\mathrm{b}=$ clear skies, $\mathrm{c}=$ cloudy, $\mathrm{g}=$ gloomy, $\mathrm{o}=$ uniform complete cloud cover, $\mathrm{q}=$ squalls, $\mathrm{r}=$ rain, $\mathrm{u}=$ ugly sky.

events in the eastern Atlantic. At about local noon 24 October, the weather at Funchal, Portugal, was reported to have been hot, and the wind blew in variable gusts as the barometer began to fall. At $1300 \mathrm{LT}$ there was an intense rainfall at the same time as a notable rise in the sea level, which by 1600 LT had swept away a main bridge in the city. By the evening of 25 October, a strong breeze blew with fine weather that continued until 1400 LT 26 October, when the storm arrived from the south and the sea surged over the beach and submerged some nearby land; the storm persisted during the evening when a great number of ships were driven ashore; at 2100 LT the wind veered to the southwest and then veered farther during the night to the northwest. The storm was described as the worst in Madeira since 1803. Reid (1849), the former governor of Bermuda and a member of the British Association for the Advancement of Science, provides the following further important and helpful details:

24 October: 8 PM light south wind reported by Numa transport in the vicinity of $2930 \mathrm{~N} 2445 \mathrm{~W}$, after which arose at north, increasing in strength, a hurricane [sic], the wind veering to north-westerly. 24 October: Falcon brigantine, in $3110 \mathrm{~N} 1945 \mathrm{~W}$ first had a SE wind, veering by the east to NE, becoming $\mathrm{N}$ and NW. In her logbook, the storm is called a hurricane, and she was hove over and nearly lost.

25 October: HMS Dee, with difficulty landed her passengers at Funchal, Madeira owing to the swell of the sea, but could not land the baggage. At 11:40 a.m. the Dee "set a-head full speed" and at noon the logbook records, "weather very fine and clear, set all sail" but by midnight the Dee was in the heart of the gale. The barometer fell from 29.95 inches at 5:30 P.M. 25 October with a southerly wind; by midnight it was 29.69 with a SW $\times$ S wind; early hours of 26 October $S \times E$ tremendous gales, very heavy rain, a heavy cross sea; 6:30 A.M. sudden shift of wind to NNE, barometer 28.50; 10 A.M. 29.10 more moderate weather; noon $\mathrm{N} \times \mathrm{W}$ weather looking better, latitude by account $3101 \mathrm{~N} 1946 \mathrm{~W}$. By midnight the barometer was up to 29.80 .

Reid also quotes reports from Funchal that the wind veered from the southeast to south to southwest on 26 October. He then describes how the storm struck the south of Spain, both demolishing houses in Seville and uprooting trees on 29 October. Several vessels from Cádiz were severely damaged. More helpfully, he notes that the Royal Navy ship HMS Warspite found herself swept up in the circulation, 
and Table 3 offers an abridged transcription of the logbook for the time of the storm. The vessel was then sailing south-southeast in the vicinity of Cape St. Vincent off the southern Portuguese coast, in the approach to the Straits of Gibraltar. The data would seem to describe the passage of a significant storm system, with the surface pressure subsiding to a minimum close to 0500 LT 29 October, and the maximum recorded force of 9 being registered shortly afterward. The veering of winds from southerly to a generally northerly quarter suggests that the system moved eastward, overtaking the vessel. The spell of easterly winds suggests also that the storm center passed to the south of the ship. Cloud cover was persistent with embedded squalls and rain, particularly on the western flanks of the storm. The wind forces indicate, however, that the vessel was perhaps spared the worst conditions.

Further evidence is provided by U.S. logbooks from the Maury Collection. Four merchant vessels were in the general vicinity of the hurricane during late October and early November. The logbooks for the Mason Barney, Cormando, and Three Brothers provide little positive evidence. All were in the area between $0^{\circ}-15^{\circ} \mathrm{N}$, $20^{\circ}-30^{\circ} \mathrm{W}$ until 1 November, but none of them indicate wind strengths greater than "moderate," while the directions are almost exclusively from the southeast quarter. Occasional squalls and rain are noted, but these are more likely to have been associated with disturbances in the nearequatorial latitudes. The logbook of the Warsaw is more informative. This ship was then sailing on a course slightly north of east some 100 miles south of Madeira, standing at $25^{\circ} \mathrm{W}$ on 20 October and reaching $16^{\circ} \mathrm{W}$ on 1 November. During this time the winds were from between the north and northeast, varying principally between either "fresh" and "hard" or "strong" gales. These gales set in as fresh on 22 October, became hard on 24 October, and then continued as strong for the next 3 days, before return-
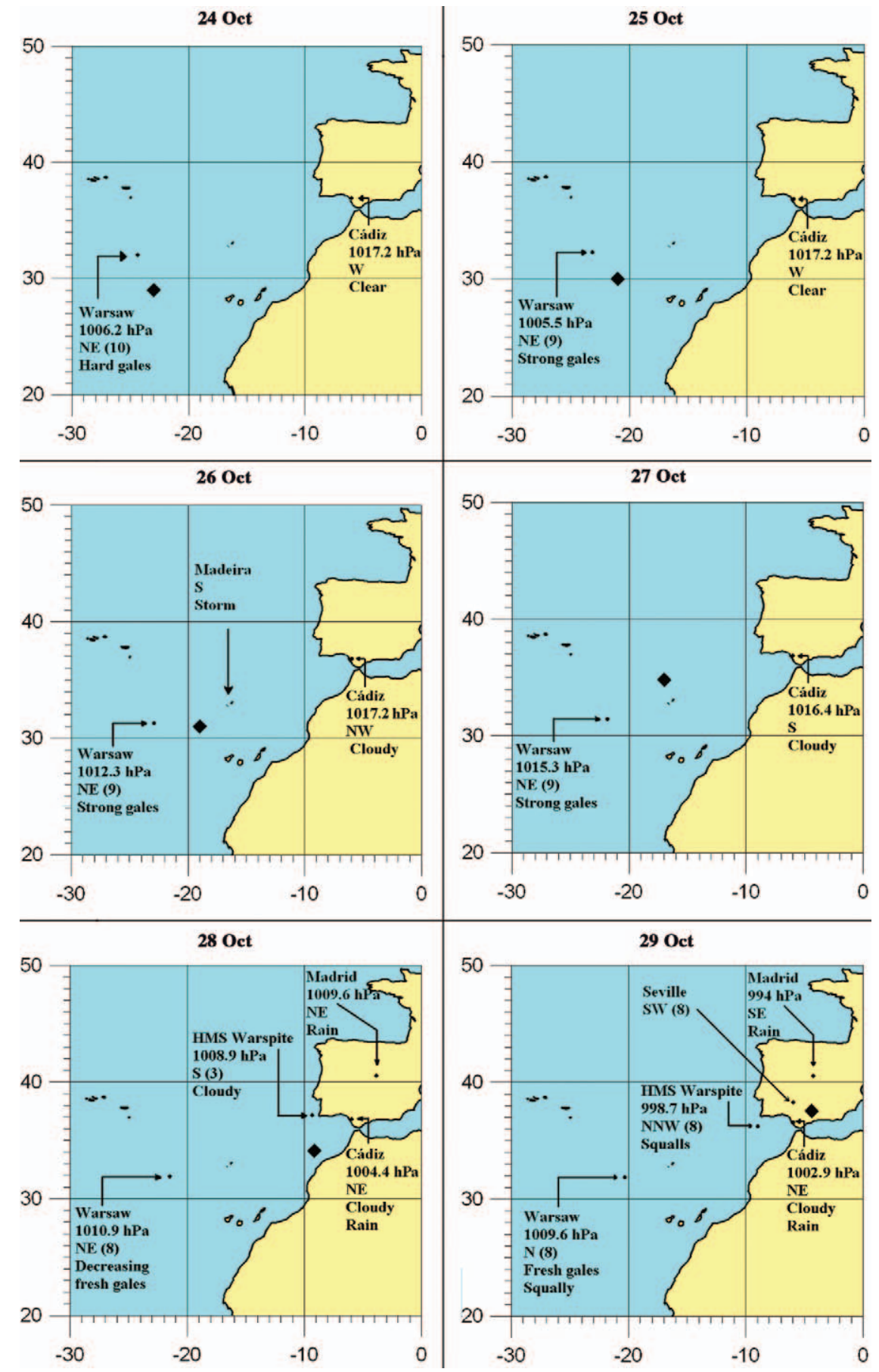

FIG. 3. Daily maps (24-29 Oct 1842) with data and estimations of the trajectory; denotes the estimated center of the storm. 
ing to fresh on 28-30 October and strong again on 31 October. Conditions were described as being "squally" throughout. Although the Beaufort scale had not at this time been formally adopted, the studies by Wheeler and Wilkinson (2004) have shown that the evolution of the nautical weather vocabulary was at this time such that these terms would have been all but identical in meaning to those of Beaufort's system. Researches by the CLIWOC project team (CLIWOC 2003) equate such strong and hard gales with Beaufort forces 9 and 10 , respectively.

Statistical detail is added by the inclusion of daily surface pressure records in this logbook. Between 20 and 25 October surface pressure fell from $1,022.7$ to $1,005.7 \mathrm{hPa}$, recovering to $1,022.7 \mathrm{hPa}$ only on 1 November when the winds began also to back to the west. Such a picture of sustained low pressure, northerly winds, and unsettled conditions suggests that the vessel found itself in more or less the same quarter of the system throughout the period. It may, therefore, have followed an eastward route parallel to that of the hurricane, and on whose western flanks it remained. The surface pressure values indicate, however, that the ship lay on the margins of the system whose central pressure, to judge by the earlier cited evidence, was probably closer to $965 \mathrm{hPa}$ and, at a rough estimate using the available data, some 200 miles from the center. Such a size, relatively small though it is, is consistent with the geographical extent of the damage noted above. Figure 3 shows daily maps with a summary of the available meteorological information (in Spain and at sea), including an estimation of the trajectory of the system.

Inferences regarding the minimum pressure of this system during its passage over the Atlantic are inevitably limited by the shortage of information. The minimum pressure measured near Madeira on board the Dee was $965.1 \mathrm{hPa}$ at $0800 \mathrm{LT} 26$ October, and possibly close therefore to the "eye" of the system. This observation would imply a category- 2 hurricane on the Saffir-Simpson scale (Brown et al. 2006). At the same time, other information can be drawn upon in order to gain an impression of the storm's character. The record from southwest Spain makes clear reference to extensive demolition of houses and uprooted trees. Such observations can be set against the so-called "landsmen's" criteria for the Beaufort scale (Met Office 1975) and suggests the strength of the wind to have been at least storm force 10, the description for which is as follows: seldom experienced inland, trees uprooted, and considerable structural damage occurs. The wind speed range then embraces this force as $48-55 \mathrm{kt}$. All of this information suggests winds with a maximum sustained surface wind (MSSW) of approximately $50 \mathrm{kt}$. We also utilized the relationships by Brown et al. (2006) to estimate the minimum sea level pressure (MSLP), assuming a pressure-wind relationship applicable in this part of the world. From the equation

$$
V_{m}=8.354(1015.8-p)^{0.6143},
$$

where $V_{m}$ is the MSSW (kt) and $p$ is the MSLP (hPa), the model provides an estimated MSLP of just $1,000 \mathrm{hPa}$, which is a figure in reasonable agreement with the data from Cádiz and in also agreement with other information and conclusions regarding its character.

The collective evidence cited above does not conflict with Reid's (1849) hypothesis that the disturbance was quickly caught by the upper westerlies and steered almost immediately to the northeast, rather than traveling westward across the Atlantic. Reid provides a tentative trajectory that is reproduced in Fig. 4a, and the evidence at hand supports his conjecture. Such events are, it should be noted, exceptionally uncommon in this region, and more recent data suggest that winds of force 9 (41-47 kt) occur less than $0.5 \%$ of the time in this area and a pressure of $985 \mathrm{hPa}$ is in the lowest percentile of observations at this time of the year (Lindau 2001).

\section{A MODERN ANALOGY TO THE I 842 EVENT: HURRICANE VINCE. The occurrence} of Hurricane Vince in October 2005 offers a useful analog of the 1842 storm. It was equally unusual in that it formed in the vicinity of Madeira and struck Spain after passing directly northeastward from its source region. According to the U.S. National Hurricane Center (NHC; Franklin 2006), Vince was a short-lived tropical cyclone, which, although growing from a low pressure system of nontropical origin that had been slow moving between the Azores and the Canary Islands, acquired tropical characteristics on 9 October. While the sea surface temperatures were a relatively modest $23^{\circ}-24^{\circ} \mathrm{C}$, the system developed beneath a large mid-/upper-level trough and it soon presented several characteristics of a tropical storm, including a banding eye and a transition to a warm-core structure. The presence of an upper trough and cold core low was the key to the development of this hurricane in otherwise less-than-auspicious conditions, the relative low sea surface temperatures being the most important, and encouraged deep and organized convection. This development was embedded within a large envelope of cyclonic flow at the surface, and created the inner 

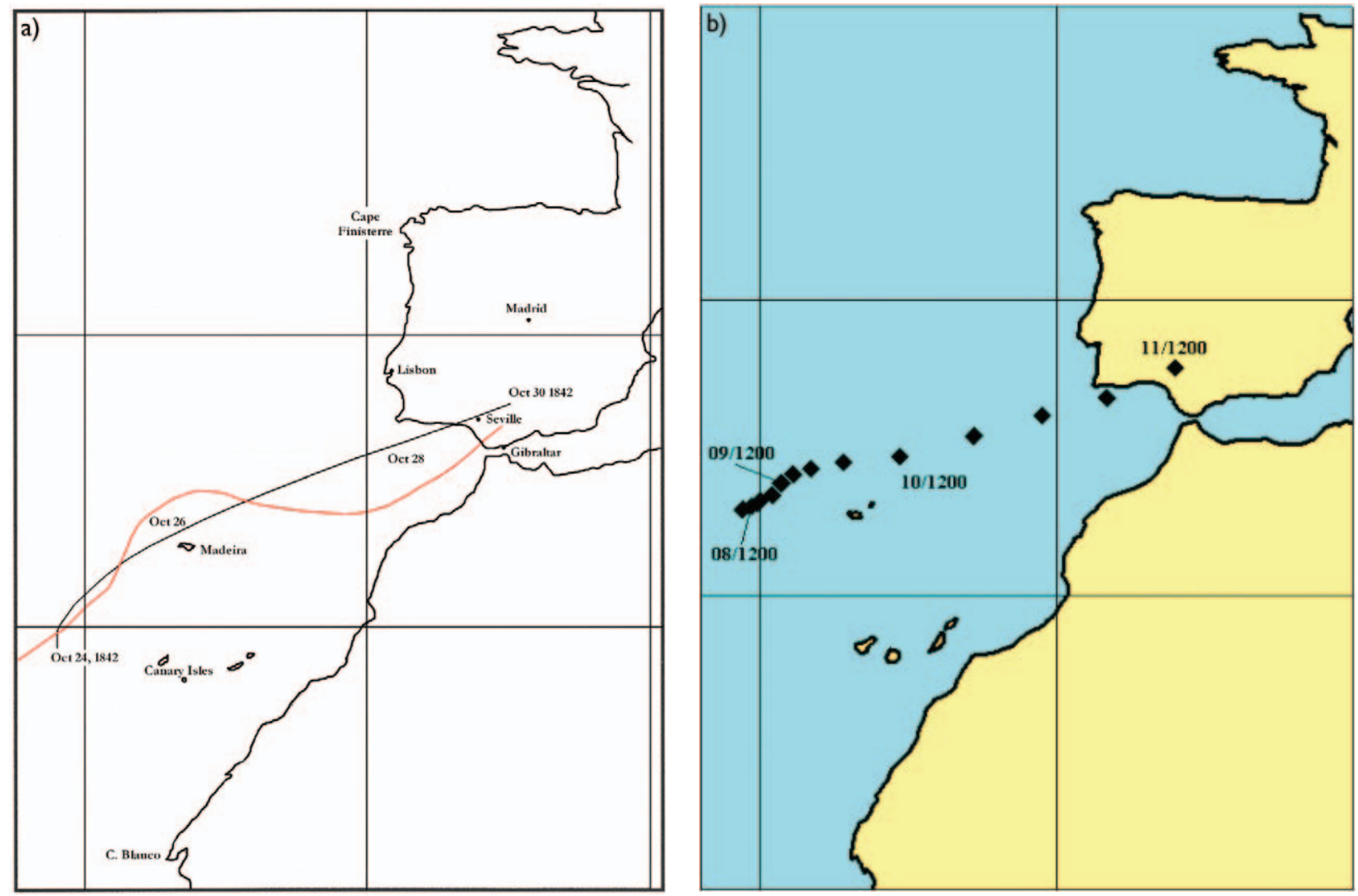

FIG. 4. (a) Reid's trajectory for the 1842 cyclone (black line). The red line is our estimation of the trajectory. (b) Trajectory of Hurricane Vince in $\mathbf{2 0 0 5}$ according to NHC best-track report.

core of convection of about $100 \mathrm{nmi}$ in diameter that soon became identifiable as an isolated system with maximum wind speeds of 20-25 kt. From its location at $34.0^{\circ} \mathrm{N}, 19.2^{\circ} \mathrm{W}$ (the first advisory issued by the NHC), a central pressure of $1,001 \mathrm{hPa}$, and winds of $45 \mathrm{kt}$, the system began moving to the northeast. The maximum stage of development was reached on 9 October with winds of $65 \mathrm{kt}$, when the system had been officially designated by the National Hurricane Center as a hurricane. It then weakened due to upper-level northwesterly winds, creating unfavorable wind shear and displacing the convective focus to the east of the storm center. Figure $4 \mathrm{~b}$ shows the reconstruction of Vince's trajectory from the National Hurricane Center's data between 1500 LT 9 October and 0900 LT 11 October, when it dissipated, becoming embedded in a frontal system after crossing Spain and the southern Portuguese coast.

Intense wind gusts and heavy precipitation were associated with its landfall on 11 October, with these being most notable in the more exposed areas of western Andalusia. The city of Ceuta (North Africa) and the provinces of Cádiz, Huelva, and Seville recorded significant precipitation, with localized accumulations of very great magnitude along the coast and farther inland. In Cordoba, for example, $84 \mathrm{~mm}$ was recorded between 1200 and $1500 \mathrm{LT}$, with a maximum 10 -min rate of $88.8 \mathrm{~mm} \mathrm{~h}^{-1}$. During this time the wind was moderate from the southeast; later it veered to the southwest, becoming more variable in character (Fig. 5). Most of the observatories of the area recorded gusts of 32-35 kt, with maximum values of $42 \mathrm{kt}$ in Jerez de la Frontera and $39 \mathrm{kt}$ in $\mathrm{D}^{\mathrm{a}}$ Mencía (INM 2005).

DISCUSSION. This paper shows that the storm of 1842 and Hurricane Vince exhibit a high degree of similarity in their trajectories (see Fig. 4), wind intensity, and affected geographic area (see Figs. 1 and 5); in this sense, the 1842 storm can be considered a historical precedent for Vince. A comparison of SLP patterns was not possible, and for 1842 only reconstructed monthly mean SLP charts are available (Luterbacher et al. 2002). Nevertheless, the evidence suggests that the two systems are analogous in behavior and trajectory. In this sense, two interesting statements were issued by the National Hurricane Center. On 10 October it was announced that 
"... Vince is a rare tropical cyclone for this part of the world"; while on 11 October the statements were yet more categorical, including "... the historical record shows no tropical cyclone ever making landfall on the Iberian Peninsula ... before becoming the first tropical cyclone to make landfall in Spain." It was not specifically stated that the latter statement was based on the period of record used by the NHC for such comparisons, which begins in 1851 and is after the events here described. In this example the use of hitherto overlooked historical and documentary sources strongly suggest that Hurricane Vince cannot be singled out as an unprecedented event.

Interestingly, and in contrast to the NHC, the Spanish National Institute of Meteorology (INM 2005), after an analysis based on satellite imagery and high-resolution observations from the area, categorized Vince as a midlatitude mesocyclone that developed from a cutoff low as early as 7 October. Such systems have cold cores, often leading to intense convection, and are created in situations in which the upper westerlies assume a very low zonal index. Nieto et al. (2005) provide a useful account of cutoff low climatology. Storms resulting from cutoff lows and low zonality of the upper westerlies are by no means unknown in this area. Such situations are of sufficient frequency and consistency of character to be widely recognized as a synoptic "type." Several such occurrences can be expected each year, with a peak incidence in autumn (Met Office 1978). The most well known, and possibly one of the most severe of such events of the nineteenth century, was the so-called Trafalgar storm that followed the famous battle (Wheeler 2001); although described by one sea captain as a "hurricane," it is almost certain that it was a cutoff feature of a wholly extratropical character and, having persisted for 7 days, was a storm of remarkable persistence and ferocity.

FINAL REMARKS. Our results strongly suggest that a hurricane formed in the eastern Atlantic Ocean and moved east-northeast to the southwest coast of Spain in late October 1842. Land-based damage reports on the Spanish coast and barometer data from both coastal stations and ships of opportunity indicate wind speeds that are, at a minimum, equivalent to tropical storm-force winds, and quite possibly even have minimal hurricane strength. Given the widespread nature of subsequent wind-induced damage reports in the interior of Spain over a wide area, we consider it likely that this hurricane became extratropical shortly after landfall or was even in the process of undergoing a transformation from tropical to extratropical status upon landfall. Either way, it is the only tropical cyclone of tropical storm intensity yet to be documented in Europe.

Documentary sources are particularly useful for the reconstruction of extreme meteorological and climatological events. The present example shows how the analysis of documents from different and independent sources can improve our knowledge of relevant historical episodes. In addition to such instrumental data that are available, the assessment of accounts, usually narrative in style, of the impacts and consequences of these events provides a more comprehensive picture, extending so far as to permit the trajectories of the systems to be reconstructed. There are a number of difficulties in conducting this type of study, which is the result of a number of factors. Among them can be cited the difficulties in gaining access to the original documents, which are frequently kept in nondigitized archives and often are dispersed among different countries. Further difficulties are presented by the need to interpret archaic terms, often without previous methodological guidelines. These challenges create great demands on time, often requiring in addition a strongly multidisciplinary approach. Nevertheless, there have been significant advances in identifying such sources, in developing methods with which these data can be treated, and in making them more accessible. Thus, the earlier hurricane chronologies since 1700 have been revised and reassessed (Chenoweth 2006) and new evidence from Atlantic hurricanes kept in Spanish archives is also becoming available (García-Herrera et al. 2005b), both of which result in a more comprehensive chronology of hurricanes and storms. In addition, a new source of information has been assessed in the logbooks of sailing ships. It is estimated that there are around 120,000 logbooks, each containing several months of daily observations, kept in the British archives for the period from 1670 to 1850 . Most of these have yet to

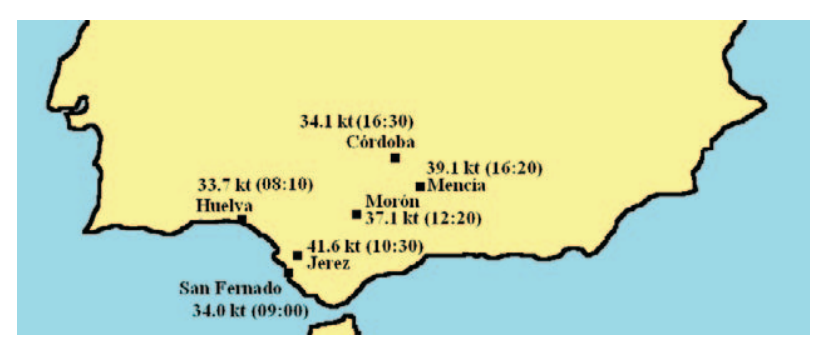

Fig. 5. Maximum wind gusts recorded in Spain on II Oct 2005 and resulting from the effects of Hurricane Vince. The map includes also (in parenthesis) the times of the gusts. 
be analyzed (D. Wheeler 2006, personal communication), but progress has been made by the recently completed European Union (EU) CLIWOC project (García-Herrera et al. 2005a) that has established the methods by which this vast fund of information can be interpreted and calibrated against instrumental records. Finally, there have been notable efforts to improve databases on severe weather events in Europe (Barriendos and Martín Vide 1998; Barriendos et al. 2002; and Barriendos 2005; Llasat et al. 2005). A systematic abstraction of these sources and their joint analysis would yield a picture of severe weather episodes for the period of 1650-1900, which is currently lacking. Much remains to be completed in this potentially fruitful field but, as this case study has amply demonstrated, careful examination of these sources can do much to provide a measured and longer-term perspective on climatic events and can help to fill important gaps in our knowledge of cyclone dynamics across the Atlantic.

ACKNOWLEDGMENTS. We gratefully acknowledge librarians at historical libraries and societies for help in collecting historical data. We also thank Henry Díaz, Ramón Pérez, and an anonymous reviewer for their comments. The Spanish Ministry of Science and Education provided partial support through Grant MEC.CGL200525107-E/CLI. Cary Mock's contribution is supported by NSF Grant ATM-0502105.

\section{REFERENCES}

Admiralty: Captains' Logs, 1669-1853, ADM 51, The National Archives, Kew, Richmond, Surrey.

Admiralty: List Books, 1673-1909, ADM 8, The National Archives, Kew, Richmond, Surrey.

Admiralty Masters' Logs, 1672-1840, ADM 52, The National Archives, Kew, Richmond, Surrey.

Barriendos, M., 2005: Climate and culture in Spain: Religious responses to extreme climatic events in the Hispanic kingdoms (16th-19th centuries). Kulturelle Konsequenzen der "Kleinen Eiszeit," W. Behringer, H. Lehmann, and C. Pfister, Eds., Vandenhoeck \& Ruprecht, 379-414.

—-, and J. Martín Vide, 1998: Secular climatic oscillations as indicated by catastrophic floods in the Spanish Mediterranean coastal area (14th-19th centuries). Climatic Change, 38, 473-491.

—_, _ J. C. Peña, and R. Rodríguez, 2002: Daily meteorological observations in Cádiz-San Fernando. Analysis of the documentary sources and the instrumental data content (1786-1996). Climatic Change, 53, 151-170.
Brázdil, R., P. Dobrovolný, Štekl, O. Kotyza, H. Valášek and J. Jež, 2004: History of Weather and Climate in the Czech Lands VI: Strong Winds. Masaryk University, $377 \mathrm{pp}$.

Brown, D. P., J. L. Franklin, and C. Landsea, 2006: A fresh look at tropical cyclone pressure-wind relationships using recent reconnaissance based "best track" data (1998-2005). Preprints, 27th Conf. on Hurricanes and Tropical Meteorology, Monterey, CA, Amer. Meteor. Soc., 3B.5.

Camuffo, D., C. Secco, P. Brimblecombe, and J. Martin Vide, 2000: Sea storms in the Adriatic Sea and the Western Mediterranean during the last Millennium. Climatic Change, 46, 209-223.

Chenoweth, M., 2006: A reassessment of historical Atlantic basin tropical cyclone activity. Climatic Change, 76, 169-240.

—- and C. W. Landsea, 2004: The San Diego hurricane of 2 October 1858. Bull. Amer. Meteor. Soc., 85, 1689-1697.

CLIWOC, 2003: CLIWOC Multi-Lingual Meteorological Dictionary. KNMI Publication 205, 49 pp.

Franklin, J. L., 2006: Tropical cyclone report: Hurricane Vince, 8-11 October 2005. National Hurricane Center, 9 pp. [Available online at www.nhc.noaa. gov/pdf/TCR-AL242005_Vince.pdf at 01/06/2006.]

García-Herrera, R., G. Können, D. Wheeler, M. R. Prieto, P. Jones, and F. Koek, 2005a: A climatological database for the world's oceans 1750-1854. Climatic Change, 73, 1-12.

— L. Limeno, P. Ribera, and E. Hernández, 2005b: New records of Atlantic hurricanes from Spanish documentary sources. J. Geophys. Res., 110, D03107, doi:10.1029/2004JD005272.

— , P. Ribera, L. Gimeno, and E. Hernández, 2007: Northwest Pacific typhoons documented by the Philippine Jesuits, 1566-1900. J. Geophys. Res., 112, D06108, doi:10.1029/2006JD007370.

INM, cited 2005: Consideraciones sobre el ciclón Vince: Sus efectos sobre la peninsula Ibérica (in Spanish). Ministerio de Medio Ambiente, Instituto Nacional de Meteorología, 20 pp.

Lamb, H. H., 1991: Historic Storms of the North Sea, British Isles and Northwest Europe. Cambridge University Press, 204 pp.

Lindau, R., 2001: Climate Atlas of the Atlantic Ocean. Springer, $514 \mathrm{pp}$.

Liu, K.-B., C. Shen, and K.-S. Louie, 2001: A 1000-year history of typhoon landfalls in Guandong, southern China, reconstructed from Chinese historical documentary records. Ann. Assoc. Amer. Geogr., 91, 453-464.

Llasat, M. C., M. Barriendos, A. Barrera, and T. Rigo, 2005: Floods in Catalonia (NE Spain) since the 14th 
Century. Climatological and meteorological aspects from historical documentary sources and old instrumental records. J. Hydrol., 313, 16-31.

Luterbacher, J., and Coauthors, 2002: Reconstruction of sea-level pressure fields over the eastern North Atlantic and Europe back to 1500. Climate Dyn., 18, 545-561.

Met Office, 1975: Observer's Handbook. 3rd ed. HSMO, $242 \mathrm{pp}$.

- 1978: The Waters off the Azores and Odd SouthWest Europe and North-West Africa, Part 1. Vol. III, Weather in the Home Waters, HMSO, 370 pp.

Mock, C., D. O. Mayes, J. Mojzisek, M. McWaters, and M. Chenoweth, 2004: Reconstructing South Carolina tropical cyclones back to the mid eighteenth century. Preprints, 26th Conf. on Hurricanes and Tropical Meteorology, Amer. Meteor. Soc., 671-672.

NCDC, cited 1998: The Maury Collection: Global Ship Observations, 1792-1910. Ashville, NC, National Climatic Data Center, CD-ROM, Version 1.0, February.

Nieto, R., and Coauthors, 2005: Climatological features of cut-off low systems in the Northern Hemisphere. J. Climate, 18, 3085-3108.

Pauling, A., J. Luterbacher, C. Casty, and H. Wanner, 2006: 500 years of gridded high-resolution precipitation reconstructions over Europe and the connection to large-scale circulation. Climate Dyn., 26, 387-405.

Redfield, W. C., 1846: On three several hurricanes of the American seas and their relations to the Northers, so called, of the Gulf of Mexico and the Bay of Honduras, with charts illustrating the same. Amer. J. Sci., 52, 162-187 and 311-334.

Reid, W., 1849: The Progress of the Development of the Law of Storms and of the Variable Winds, with the Practical Application to the Subject of Navigation. Palmer and Clayton, $530 \mathrm{pp}$.

Ribera, P., R.García-Herrera, L. Gimeno, and E. Hernández, 2005: Typhoons in the Philippine Islands, 1901-1934. Climate Res., 29, 85-90.

Rico Sinobas, M., 1853: Estudio del huracán que pasó sobre una parte de la Península española el día 29 de octubre de 1842. Mem. R. Acad. Cienc. Exactas Fis. Nat., III, 45-73.

Vaquero, J. M., M. C. Gallego, and J. A. García, 2003: Auroras in the Iberian Peninsula (1700-1855) from Rico Sinobas' Catalogue. J. Atmos. Solar-Terr. Phys., 65, 677-682.

Wheeler, D., 2001: The weather of the European Atlantic Seaboard during October 1805: An exercise in historical climatology. Climatic Change, 48, 361-385.

— , and C. Wilkinson, 2004: From calm to storm: The origins of the Beaufort wind scale. Mar. Mirror, 90, 187-201. 